\title{
Sustained Release for St. John's Wort: A Rational Idea?
}

Lucia Disch $^{1,2}$, Kristina Forsch ${ }^{1}$, Beate Siewert ${ }^{1}$, Jürgen Drewe ${ }^{1^{*}}$ and Gert Fricker ${ }^{2}$

${ }^{1}$ Max Zeller Söhne AG, CH-8590 Romanshorn, Switzerland

${ }^{2}$ Ruprecht-Karls-University, D-69120 Heidelberg, Germany

\begin{abstract}
Purpose: Aim of this study was to evaluate St. John's wort (SJW) extract for its suitability to be formulated in a sustained release dosage form using Ze 117 as example extract.

Methods: Hypericin as marker for naphtodianthrones and quercetin as marker for contained flavonoids in Ze 117 were evaluated for solubility through shake flask method and for in vitro permeability through Caco-2 monolayers. Furthermore, different intestinal segments were screened for absorption capacity of markers using an in situ rat model.

Results: Over a physiological $\mathrm{pH}$ range, naphthodianthrones exhibited $\mathrm{pH}$-dependent solubility profiles with best solubility at $\mathrm{pH} 6.8$. In contrast, solubility of flavonoids was $\mathrm{pH}$-independent. In Caco-2 monolayer system, low permeation was evident for naphthodianthrone hypericin, while the flavonoid quercetin showed high permeation. Results of in situ rat model showed absorption of hypericin and quercetin mainly in jejunum.

Conclusion: SJW extract covers components with different physicochemical properties. Predominant absorption in rat intestinal segments indicated presence of an absorption window in small intestine. Furthermore, there is high drug concentration per single dose in combination with a complex extract mixture. Thus, development of a sustained release formulation for SJW extract is challenging.
\end{abstract}

Keywords: Hypericum perforatum, St. John's wort, BCS, Caco-2 cells, Intestinal absorption, In situ rat model, Solubility, Bioavailability

Abbreviations: SJW: St. John's wort; Ze 117: St. John's wort extract of Max Zeller Söhne AG (Romanshorn, Switzerland); HRS: Herbal reference substance; EP: European Pharmacopoeia; USP: United States Pharmacopoeia; BCS: Biopharmaceutics classification system; ab: Apical-to-basolateral compartment; ba: Basolateral-toapical compartment; $\mathrm{P}_{\text {app }}$ : Apparent permeability; $\mathrm{R}_{\mathrm{E}}$ : Efflux ratio; $\mathrm{R}_{\mathrm{M}}$ : Recovery rate; TEER: trans-epithelial electrical resistance; PK: Pharmacokinetics; $\mathrm{C}_{\max }$ : Maximum plasma concentration; $\mathrm{t}_{\max }$ : Time to maximum plasma concentration; AUC: Area under the curve; $A_{\text {purs }}$ : Area under the curve related to length of intestinal segment and transit time; SEM: Standard error of the mean; RSD: Relative standard deviation; HPLC: High performance liquid chromatography; UPLC: Ultra-high performance liquid chromatography; UV/Vis: Ultraviolet/visible light (detector for HPLC); MS: Mass spectrometry; ES-: MS ionization source in negative ion mode; $\mathrm{m} / \mathrm{z}$ : Mass to charge ratio; SIR: Selected ion recording; SR: Sustained release.

\section{Introduction}

In order to improve patient compliance and to provide an ideal efficiency side effect profile, sustained release (SR) products came in the focus of pharmaceutical development [1]. However, there are hardly any products with sustained release kinetic among herbal medicinal drugs. To target a therapy improvement for St. John's wort (SJW) products, the aim of this study was to evaluate SJW extract for sustained release suitability. Clinical relevance demonstrates oral administration of SJW as valuable alternative to conventional antidepressant drugs [2,3]. Committee of Herbal Medicinal Products (HPMC) of the European Medicines Agency (EMA) granted Hypericum perforatum with wellestablished use status for the treatment of mild to moderate depressive episodes as well as for short-term treatment of symptoms in mild depressive disorders [4].
The compounds in SJW cover a large range of substances of which numerous show biological activity. Flavonoids represent the greatest part of secondary metabolites with an amount of $2 \%$ up to $4 \%$. Beneath the flavonol glycosides rutin, hyperoside, isoquercetrin and quercetrin as major flavonoids, there are also smaller amounts of the flavonol aglycon quercetin as well as biflavonoids such as biapigenin and amentoflavone [5]. Naphtodianthrones namely hypericin and pseudohypericin occur in small amounts up to $0.3 \%$ in the flowers and leaves mainly in the dark glands [6]. The occurrence of the phloroglucinol hyperforin in the above ground parts mainly in the transluscent glands [7] is characteristic for SJW. Another phloroglucinol, adhyperforin which is a methyl analogous of hyperforin, occurs in flowers and stems in a concentration of $0.8-1.8 \%$. Additionally, SJW contains the phenolcarbon acids caffeic acid and chlorogenic acid as well as proanthocyanidins, tannins, etheric oils, fatty acids and chlorophyllin [8]. Pharmacological activity was evident for hypericin $[9,10]$. However, high doses of pure hypericin were necessary for reaching pharmacological activity, which can be barely achieved by administration of total SJW extract due to the low water solubility of hypericin. An explanation for this conflict in theory and praxis could be that solubility of pure hypericin in water is increased by some phenolic constituents typical for SJW extracts especially by procyanidins and hyperoside [11]. This synergistic effect may lead to an increase in the

*Corresponding author: Jürgen Drewe, Max Zeller Söhne AG, CH-8590 Romanshorn, Switzerland, Tel: +41 7146605 46, Fax: +41(0)71 46607 07; E-mail: juergen.drewe@zellerag.ch

Received October 26, 2017; Accepted November 16, 2017; Published November 27, 2017

Citation: Disch L, Forsch K, Siewert B, Drewe J, Fricker G (2017) Sustained Release for St. John's Wort: A Rational Idea? J Bioequiv Availab 9: 565-576. doi: 10.4172/jbb.1000363

Copyright: (c) 2017 Disch L, et al. This is an open-access article distributed under the terms of the Creative Commons Attribution License, which permits unrestricted use, distribution, and reproduction in any medium, provided the original author and source are credited. 
oral bioavailability of hypericin. Accordingly, the pharmacological activity of hypericin and pseudohypericin was enhanced in the forced swimming test when combined with the procyanidin fraction [12]. Also, the combination with rutin leads to a strong increase of the effect in the forced swimming test [13]. In addition, flavonoids such as hyperoside and rutin as well as the quercetin metabolite isorhamnetin were shown to have pharmacologic activity [14]. Correlation of hyperforin with the antidepressant effect of total SJW extract is not ensured [15]. In summary, no mechanism of action neither active compounds of SJW are clearly determined. Therefore, the whole extract is observed as active ingredient and European Pharmacopoeia monographed SJW as quantified extract (Type B1) (EP 9.3/1438).

For quality control of SJW extracts, there have been defined analytical markers in European Pharmacopoeia (EP 9.3/1874), e.g. naphtodianthrones calculated as hypericin, flavonoids and phloroglucinols calculated as hyperforin. However, hyperforin was identified as key component in SJW causing drug-drug interactions Moore [16]. This was the reason for selecting SJW extract Ze 117 for SR evaluation since it contains only low amounts of hyperforin $(\leq 0.2 \%)$. SJW extracts with low dose hyperforin such as Ze 117 showed reduced or no relevant clinical interactions [17-20]. Hypericin and flavonoids such as quercetin were selected as analytical marker for extract characterization based on EP monograph (EP 9.3/1874). Plasma halflives of flavonoids contained in SJW extract are about 4 hours [21]. For active substances with short half-lives, SR systems reduce peak plasma concentrations and prolong the presence of therapeutic plasma levels. Half-lives of hypericin in plasma was about between 19 hours [21] up to 29.1 hours [22] and demand no SR formulation. However, flavonoids may benefit from a sustained release delivery system.

To evaluate SR suitability of SJW extract, pH-dependent thermodynamic solubility was determined for analytical markers in $\mathrm{Ze}$ 117 using an in vitro shake flask method. Absorption properties were estimated by in vitro permeation through Caco-2 cell monolayers. Finally, different intestinal segments were screened for appropriate absorption capacity using an in situ rat model.

\section{Materials and Methods}

SJW dry extract Ze 117 was provided by Max Zeller Söhne AG (Romanshorn, Switzerland). The used batch of Ze 117 (batch no. 142408) contained $0.1 \%$ of hyperforin. Hypericin and quercetin were purchased form PhytoLab (Vestenbergsgreuth, Germany). Glycerol was purchased from Impag AG (Zurich, Switzerland). Caco-2 cells HTB37TM of lot number 2463681 were obtained from ATCC (American Type Culture Collection, Manassas, VA, USA). Dulbecco's modified eagle serum (DMEM), non-essential amino acids, Gibco GlutaMAX containing $200 \mathrm{mM}$ L-alanyl-L-glutamine dipeptide in $0.85 \% \mathrm{NaCl}$ and penicillin/streptomycin were from Thermo Fisher Scientific (Reinach, Switzerland). Hank's balanced salt solution (HBSS) buffer, dimethyl sulfoxide (DMSO), acetonitrile, formic acid, (4-(2-hydroxyethyl)-1piperazineethanesulfonic acid (HEPES), propranolol hydrochloride, digoxin, fluorescein isothiocyanate-dextran (FITC-dextran), SJW dry extract HRS as well as rutin trihydrate and sodium hydroxide solution were obtained from Sigma-Aldrich (Buchs, Switzerland). All other chemicals were purchased from Merck (Darmstadt, Germany). Wild type male Sprague Dawley rats from Janvier Labs (Le Genest-Saint-Isle, France) were used.

\section{Caco-2 cell culture}

For transport assay, Caco-2 cells were seeded on $0.336 \mathrm{~cm}^{2}$ PET (polyethylene terephthalate) filters and 24 well plates with a density of $1 \times 10^{5}$ cells per $\mathrm{cm}^{2}$. Caco- 2 cells were used 21 days post seeding in passage 74 . The cells were maintained in DMEM supplied with $10 \%$ fetal bovine serum (FBS), $1 \%$ L glutamine, $1 \%$ non-essential amino acids and penicillin/streptomycin $\left(10 \mathrm{mg} \mathrm{mL}^{-1}\right)$ at $37^{\circ} \mathrm{C}$ in an atmosphere of $5 \% \mathrm{CO}_{2}$ and $90 \%$ relative humidity. Culture medium was changed every 23 days.

\section{Animals}

The in situ study was performed at the Department of Pharmacy and Molecular Biotechnology at University of Heidelberg. All procedures involving animals and their care were conducted according to European Union (EEC Council Directive 86/609, OJ L 358, 1; 12 December 1987) and were approved by the local authorities. Wild type male Sprague Dawley rats of 200-300 g weight were acclimatized and fasted overnight with free access to water.

\section{Methods}

As herbal extracts contain a complex mixture of physicochemical different constituents, analytical markers were selected. Hypericin and pseudohypericin served as surrogates for contained naphthodianthrones in SJW extract. For flavonoids that represent the greatest part of secondary metabolites in SJW [5], beneath flavonol glycosides rutin, hyperoside, isoquercetrin and quercetrin as major flavonoids, also flavonol aglycon quercetin as well as biflavonoid biapigenin served as surrogate. Figure 1 gives an overview about the structural formulas of selected markers. Solubility samples and dissolution samples were quantified for the naphthodianthrones hypericin and pseudohypericin as well as for the flavonoids rutin, hyperoside, isoquercetrin, quercetrin, quercetin and biapigenin both as single markers and as sum of naphtodianthrones and sum of flavonoids, respectively. In the scope of Caco-2 cell monolayer assay, hypericin was selected to serve as surrogate for naphtodianthrones and quercetin accordingly for flavonoids. In plasma samples, hypericin, pseudohypericin and quercetin were quantified. Additionally, plasma samples were screened for tamarixetin and isorhamnetin as metabolites of quercetin. For considering influence of other extract constituents on the performance of selected analytical marker, experiments were performed using Ze 117 in its entity.

\section{pH-dependent thermodynamic solubility}

To determine $\mathrm{pH}$-dependent thermodynamic solubility, shake flask method according to Yalkowsky was used [23], where the test substance was shaken over a defined period of 48 hours in a flask containing the test medium whereby a balance between solid substance (solute) and dissolved substance (solution) appeared. Sodium phosphate buffers of $\mathrm{pH} 1.2,2.2,3.2,4.5,5.5,6.8$ and 7.5 were prepared according USP and EP recommendations. Amounts of $2.5 \mathrm{~g}$ SJW dry extract Ze 117 each were weighed out in $50 \mathrm{~mL}$ Erlenmeyer flasks. After adding $25 \mathrm{~mL}$ of the appropriate buffer medium, Erlenmeyer flasks were closed. Then, the flasks were shaken in a water bath Julabo SW 22 at $37^{\circ} \mathrm{C}\left( \pm 1^{\circ} \mathrm{C}\right)$ and $90 \mathrm{rpm}$ for 48 hours. Samples of buffer solution were taken after 24 and 48 hours by using a $5 \mathrm{~mL}$ syringe. Samples were filtered through a syringe glass filter $(0.45 \mu \mathrm{m})$ by discarding the first $\mathrm{mL}$ of the filtrate. Three replicate determinations of solubility for each buffer were performed. The samples were quantified for naphthodianthrones and flavonoids using an HPLC-UV/V is method, which is described below. 


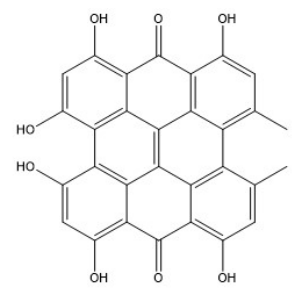

hypericin

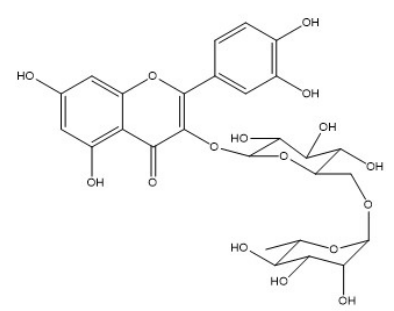

rutin

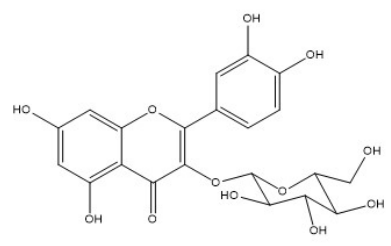

isoquercetrin<smiles></smiles>

quercetin<smiles></smiles>

pseudohypericin

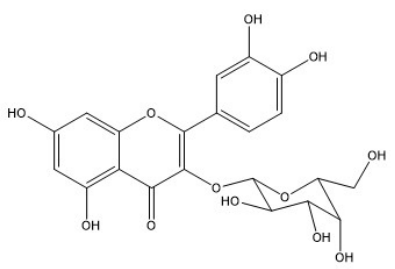

hyperoside<smiles>CC(C)C(C)COc1c(-c2ccc(O)c(O)c2)oc2cc(O)cc(O)c2c1=O</smiles>

quercetrin<smiles></smiles>

biapigenin

Figure 1: Structural formulas of naphthodianthrones and flavonoids selected as analytical marker.

\section{Caco-2 cell monolayer permeability assay}

Permeation of hypericin and quercetin was measured from apical to basolateral side (ab) and from basolateral-to-apical side (ba) in six-fold determination. The analytical marker substances hypericin and quercetin were dissolved with concentrations of $2.5 \mu \mathrm{M}$ as single substances, in presence of each other as well as in the matrix of SJW dry extract Ze 117 in HBSS supplemented with 10 mM HEPES (pH 7.4) and $1 \%$ DMSO as transport buffer. Caco-2 cells on PET filters in 24well plates were used for the permeability assay 21 days post seeding. For testing ab permeability, the volume of test solution added to the apical side (donor) was $500 \mu \mathrm{L}$ whereas the basolateral side (acceptor) was filled with $1000 \mu \mathrm{L}$ of transport buffer. Accordingly, for testing ba permeability, the volume of test solution added to the basolateral side (donor) was $1100 \mu \mathrm{L}$ whereas the apical side (acceptor) was filled with $400 \mu \mathrm{L}$ of transport buffer. During the assay, the well plates were placed on a horizontal shaker at $37{ }^{\circ} \mathrm{C}$ and gently shaken for 180 minutes. Samples of the donor compartment of $100 \mu \mathrm{L}$ each were taken at 0 and 180 minutes. Samples of the acceptor compartment $(100 \mu \mathrm{L})$ were taken after 60,120 and 180 minutes and replaced by $100 \mu \mathrm{L}$ transport buffer. TEER (transepithelial electrical resistance) was measured using a Millicell ERS voltmeter with chopstick electrodes from Merck Millipore (Darmstadt, Germany) at room temperature before and after the Caco2 cell assay. The substance flux $\mathrm{dc} / \mathrm{dt}(\mu \mathrm{mol} / \mathrm{mL} / \mathrm{s})$ for hypericin and quercetin was calculated through linear regression of the accumulated concentration in the acceptor compartment as a function of time. The apparent permeability $\mathrm{P}_{\text {app }}(\mathrm{cm} / \mathrm{sec})$ was calculated according to Artursson [24], where A is the surface area of the membrane $\left(\mathrm{cm}^{2}\right), \mathrm{C}_{0}$ is the concentration in donor compartment at start of the assay $(\mu \mathrm{mol} /$ $\mathrm{mL})$ and $\mathrm{V}_{\mathrm{A}}$ is the volume of the acceptor compartment $\left(\mathrm{cm}^{3}\right)$ :

$$
\mathrm{P}_{\text {app }}=\mathrm{dc} / \mathrm{dt} \times(1) /\left(\left(\mathrm{A} \mathrm{x} \mathrm{C}_{0}\right)\right) \times \mathrm{V}_{\mathrm{A}}
$$

Efflux ratio $R_{E}$ was calculated as quotient of apparent permeability in ba direction and apparent permeability in ab direction:

$$
\mathrm{R}_{\mathrm{E}}=\left(\mathrm{P}_{\mathrm{app}} \mathrm{ba}\right) /\left(\mathrm{P}_{\text {app }} \mathrm{ab}\right)
$$

The recovery rate $R_{M}$ was calculated by examining the amount of the analytical marker, respectively, in donor compartment $n_{t D}$ and 
acceptor compartment $\mathrm{n}_{\mathrm{tA}}$ after 180 minutes in comparison with the amount of the analytical marker in donor compartment $\mathrm{n}_{0}$ before start of the assay:

$$
\mathrm{R}_{\mathrm{M}}=\left(\mathrm{n}_{\mathrm{tD}}+\mathrm{n}_{\mathrm{tA}}\right) / \mathrm{n}_{0}
$$

The TEER values $\left(\Omega \times \mathrm{cm}^{2}\right)$ were calculated as product of measured resistance $\mathrm{R}(\Omega)$ in Caco-2 cell monolayers, corrected by measured resistance without cells $\mathrm{R}_{\text {blank }}$, and the surface area of the used filters $\mathrm{A}$ $\left(0.336 \mathrm{~cm}^{2}\right)$ :

\section{$\mathrm{TEER}=\left(\mathrm{R}-\mathrm{R}_{\text {blank }}\right) \times \mathrm{A}$}

In order to evaluate determined $\mathrm{P}_{\text {app }}$ values and efflux ratios, permeation of reference substances propranolol, metoprolol, verapamil, digoxin, furosemide, hydrochlorothiazide and FITC dextran was determined analogously. (Figure A1)

\section{In situ absorption study}

SJW dry extract Ze 117 was dissolved in a mixture of glycerol and purified water (1:1) in a concentration of $25 \mathrm{mg} / \mathrm{mL}$ in addition of hypericin $(0.3 \mathrm{mg} / \mathrm{mL})$. Male Sprague Dawley rats were fasted overnight with free access to water and then anesthetized by intraperitoneal injection of $50 \mathrm{mg} / \mathrm{kg}$ pentobarbital prior to the experiment. The peritoneum was opened by a midline incision and approximately $5 \mathrm{~cm}$ of the appropriate intestinal segment (duodenum, jejunum, ileum or colon) was ligated by using a medicinal suture. Ligation was performed in a way to avoid pass over of intestinal content but keeping an intact intestinal blood supply. The herbal extract solution of SJW dry extract was administered directly into the ligated intestinal segment in a concentration of $37.5 \mathrm{mg}$ or $75.0 \mathrm{mg}$ Ze 117 dry extract per kg rat body weight. Injection volumes were between $250 \mu \mathrm{L}$ and $750 \mu \mathrm{L}$, dependently on dose and rat body weight. Blood samples of 200 $\mu \mathrm{L}$ were taken at $0,30,60,120$ and 180 minutes from the portal vein to minimize influence of hepatic first pass effect. Blood samples were filled in Li Heparin microvettes and centrifuged for 5 minutes at 16’000 g. The plasma was separated and stored in appropriate vials at $-20^{\circ} \mathrm{C}$ until analytical quantification via UPLC MS/MS as described below. A 4 -fold determination was performed.

\section{Analytical methods}

For quantification of naphthodianthrones and flavonoids in solubility samples, dissolution samples, Caco-2 cell samples and plasma samples, HPLC-UV/Vis or UPLC MS/MS methods were used. Table 1 lists an overview.

Assay of naphthodianthrones and flavonoids in solubility and dissolution samples was performed via HPLC UV/Vis based on European Pharmacopeia. The system consisted of a Waters Acquity quaternary pump with autosampler coupled to a Waters diode array detector (Waters AG, Baden Daettwil, Switzerland) and connected to a PC running Waters Empower software. Liquid chromatography for naphthodianthrones was performed using 39 volumes of ethyl acetate mixed with 41 volumes of a $15.6 \mathrm{~g} / \mathrm{L}$ solution of sodium dihydrogen phosphate adjusted to $\mathrm{pH} 2$ with phosphoric acid and 160 volumes of methanol as mobile phase. An isocratic mode with a flow rate of 1.0 $\mathrm{mL} / \mathrm{min}$ was used. Injection volume was set to $20 \mu \mathrm{L}$. Separation was performed on a Waters HPLC column Atlantis dC18, 150 x $4.6 \mathrm{~mm}, 5$ $\mu \mathrm{m}$ (Waters AG, Baden Daettwil, Switzerland) at a column temperature of $40^{\circ} \mathrm{C}$. Detection wavelength was $590 \mathrm{~nm}$ and as reference substance, SJW dry extract HRS was used. LC for flavonoids was performed using $0.3 \%$ phosphoric acid in water as aqueous phase (A) and $0.3 \%$ phosphoric acid in acetonitrile as organic phase (B) in a gradient mode of \% A $(\mathrm{t}(\mathrm{min})), 82(0.0)-82(8.0)-47(18.0)-3(18.1)-3$ (31.0) - $82(31.1)-82(33.0)$. Injection volume was set to $10 \mu \mathrm{L}$ and the pump flow rate to $1.0 \mathrm{~mL} / \mathrm{min}$. Separation was performed on a Phenomenex HPLC column Luna C18, 150 x $4.6 \mathrm{~mm}, 3 \mu \mathrm{m}$

\begin{tabular}{|c|c|c|c|c|c|c|c|c|c|c|c|}
\hline \multirow{2}{*}{$\begin{array}{c}\text { Assay } \\
\text { application }\end{array}$} & \multirow[t]{2}{*}{ Analyte } & \multirow[t]{2}{*}{ System } & \multirow[t]{2}{*}{ Column } & \multicolumn{2}{|c|}{ Mobile phase } & \multicolumn{2}{|c|}{ Gradient } & \multirow{2}{*}{\begin{tabular}{|c|}
$\begin{array}{c}\text { Oven } \\
\text { temp. }\end{array}$ \\
{$\left[{ }^{\circ} \mathrm{C}\right]$} \\
\end{tabular}} & \multirow{2}{*}{$\begin{array}{l}\text { Flow rate } \\
\text { [mL/min] }\end{array}$} & \multirow{2}{*}{$\begin{array}{c}\begin{array}{c}\text { Injection } \\
\text { volume }\end{array} \\
{[\mu \mathrm{L}]}\end{array}$} & \multirow[t]{2}{*}{ Detection } \\
\hline & & & & A & B & $\begin{array}{l}\text { Time } \\
\text { [min] }\end{array}$ & $\begin{array}{l}\text { A\% } \\
{[\mathrm{V} / \mathrm{V}]}\end{array}$ & & & & \\
\hline $\begin{array}{l}\text { solubility, } \\
\text { dissolution }\end{array}$ & $\begin{array}{c}\text { naphto- } \\
\text { dianthrones }\end{array}$ & $\begin{array}{l}\text { HPLC-UVI } \\
\text { Vis }^{*}\end{array}$ & $\begin{array}{c}\text { Atlantis } \\
\text { dC18 } \\
150 \times 4.6 \mathrm{~mm} \\
5 \mu \mathrm{m}\end{array}$ & $\begin{array}{c}\text { Ethyl acetate, } \\
\mathrm{NaH}_{2} \mathrm{PO}_{4} 15.6 \mathrm{~g} / \mathrm{L} \\
\mathrm{pH}_{2} \text {, methanol } \\
39: 41: 160 \mathrm{~V} / \mathrm{V}\end{array}$ & - & - & - & 40 & 1.0 & 20 & $\begin{array}{l}\text { DAD } \\
590 \mathrm{~nm}\end{array}$ \\
\hline $\begin{array}{l}\text { solubility, } \\
\text { dissolution }\end{array}$ & flavonoids & $\begin{array}{c}\text { HPLC-UVI } \\
\text { Vis }^{*}\end{array}$ & $\begin{array}{c}\text { Luna } \\
\text { C18 } \\
150 \times 4.6 \mathrm{~mm} \\
3 \mu \mathrm{m}\end{array}$ & $\begin{array}{l}\text { Water, phosphoric } \\
\text { acid 1000:3 V/V }\end{array}$ & $\begin{array}{c}\text { Acetonitrile, } \\
\text { phosphoric } \\
\text { acid } \\
\text { 1000:3 V/V }\end{array}$ & $\begin{array}{c}0.0 \\
8.0 \\
18.0 \\
18.1 \\
31.0 \\
31.1 \\
33.0\end{array}$ & $\begin{array}{c}82 \\
82 \\
47 \\
3 \\
3 \\
82 \\
82\end{array}$ & 20 & 1.0 & 10 & $\begin{array}{c}\text { DAD } \\
360 \mathrm{~nm}\end{array}$ \\
\hline $\begin{array}{l}\text { in vitro Caco-2 } \\
\text { assay, } \\
\text { in situ studies } \\
\text { in rat }\end{array}$ & hypericin & $\begin{array}{l}\text { UPLC-MS/ } \\
\text { MS" }^{*}\end{array}$ & $\begin{array}{c}\text { Acquity BEH } \\
\text { C18 } \\
100 \times 2.1 \mathrm{~mm} \\
1.7 \mu \mathrm{m}\end{array}$ & $\begin{array}{c}\text { Ammonium } \\
\text { acetate in water } \\
10 \mathrm{mM}\end{array}$ & Acetonitrile & $\begin{array}{l}0.0 \\
2.0 \\
3.0 \\
3.1 \\
4.5\end{array}$ & $\begin{array}{l}40 \\
10 \\
10 \\
40 \\
40\end{array}$ & 50 & 0.7 & 10 & $\begin{array}{c}\text { ES- } \\
\mathrm{m} / \mathrm{z} 405.07 \\
\mathrm{~m} / \mathrm{z} 486.96\end{array}$ \\
\hline $\begin{array}{c}\text { in vitro Caco-2 } \\
\text { assay, } \\
\text { in situ studies } \\
\text { in rat }\end{array}$ & quercetin & $\begin{array}{c}\text { UPLC-MS/ } \\
\mathrm{MS}^{* *}\end{array}$ & $\begin{array}{c}\text { Acquity BEH } \\
\text { C18 } \\
100 \times 2.1 \mathrm{~mm} \\
1.7 \mu \mathrm{m}\end{array}$ & $\begin{array}{c}\text { Purified water, } \\
0.1 \% \text { Formic acid }\end{array}$ & $\begin{array}{l}\text { Acetonitrile, } \\
0.1 \% \text { Formic } \\
\text { acid }\end{array}$ & $\begin{array}{l}0.0 \\
4.0 \\
4.1 \\
5.0 \\
5.1 \\
6.5\end{array}$ & $\begin{array}{c}90 \\
40 \\
5 \\
5 \\
90 \\
90\end{array}$ & 50 & 0.5 & 10 & $\begin{array}{c}\text { ES- } \\
\mathrm{m} / \mathrm{z} 151.05 \\
\mathrm{~m} / \mathrm{z} 151.00\end{array}$ \\
\hline
\end{tabular}

*HPLC-UV/Vis on a Waters Acquity quaternary pump with autosampler coupled to a Waters diode array detector (Waters AG, Baden-Daettwil, Switzerland) and connected to a $P C$ running Waters Empower software

"UPLC-MS/MS on a Waters H-class system with an autosampler and a quaternary pump coupled to a Waters Xevo TQ-S tandem (triple) quadrupole spectrometer and Waters MassLynx software. Detection in multiple reaction monitoring (MRM) with an atmospheric pressure ionization source in negative ion mode (ESI-), capillary voltage of $2.5 \mathrm{kV}$, source temperature of $450^{\circ} \mathrm{C}$ and a sampling rate of $2 \mathrm{~Hz}$, transition of 503.10 to 405.07 for hypericin and 519.22 to 486.96 for pseudohypericin, transition of 301.16 to 151.05 for quercetin and 315.16 to 151.00 for tamarixetin and isorhamnetin.

Table 1: Analytical methods for quantification of naphthodianthrones and flavonoids. 
(Phenomenex, Torrance, CA, USA) at a column temperature of 20 ${ }^{\circ} \mathrm{C}$. Detection wavelength was $360 \mathrm{~nm}$ and as reference substance, rutin trihydrate was used. Both naphtodianthrones hypericin and pseudohypericin were calculated as hypericin whereas flavonoids were calculated as rutin.

Assay for hypericin and quercetin in Caco-2 cell samples was performed via UPLC MS/MS. The system consisted of a Waters Acquity quaternary pump with autosampler coupled to a Waters Xevo TQ S spectrometer (Waters AG, Baden Daettwil, Switzerland) and connected to a PC running Waters MassLynx software. Separation was done on an Acquity UPLC column BEH C18, $150 \times 2.1 \mathrm{~mm}, 1.7 \mu \mathrm{m}$ (Waters AG, Baden Daettwil, Switzerland). LC for hypericin was performed using $10 \mathrm{mM}$ ammonium acetate in water as aqueous phase (A) and acetonitrile as organic phase (B) in a gradient mode of $\% \mathrm{~A}(\mathrm{t}(\mathrm{min}))$, $40(0.0)-10(2.0)-10(3.0)-40(3.1)-40(4.5)$. Injection volume was set to $10 \mu \mathrm{L}$ and the pump flow rate to $0.7 \mathrm{~mL} / \mathrm{min}$. Transition of $(\mathrm{m} / \mathrm{z}) 503.10$ to the monitoring ion $(\mathrm{m} / \mathrm{z}) 405.07$ for hypericin and $(\mathrm{m} / \mathrm{z}) 519.22$ to the monitoring ion $(\mathrm{m} / \mathrm{z}) 486.96$ for pseudohypericin was detected. An atmospheric pressure ionization source in negative ion mode (ESI-) with capillary voltage of $2.5 \mathrm{kV}$, source temperature of $450^{\circ} \mathrm{C}$ and a sampling rate of $2 \mathrm{~Hz}$ was used. LC for quercetin and its metabolites tamarixetin and isorhamnetin was performed using 0.1 $\%$ formic acid in water as aqueous phase (A) and $0.1 \%$ formic acid in acetonitrile as organic phase $(\mathrm{B})$ in a gradient mode of $\% \mathrm{~A}(\mathrm{t}(\mathrm{min})), 90$ $(0.0)-40(4.0)-5(4.1)-5(5.0)-90(5.1)-90$ (6.5). Injection volume was set to $10 \mu \mathrm{L}$ and the pump flow rate to $0.5 \mathrm{~mL} / \mathrm{min}$. Transition of $(\mathrm{m} / \mathrm{z}) 301.16$ to the monitoring ion $(\mathrm{m} / \mathrm{z}) 151.05$ for quercetin in an atmospheric pressure ionization source in negative ion mode (ESI) with capillary voltage of $2.5 \mathrm{kV}$, source temperature of $450^{\circ} \mathrm{C}$ and a sampling rate of $2 \mathrm{~Hz}$ was used.

Plasma samples from rat taken after intestinal administration of $\mathrm{Ze}$ 117 were pooled for each sampling point to enable sample work up for naphthodianthrones and additionally for quercetin. For determination of hypercin and pseudohypericin, $50 \mu \mathrm{L}$ of each plasma sample were pipetted into an Eppendorf tube. $1.5 \mathrm{~mL}$ ethylacetate were added and the samples were shaken overhead for 10 minutes. The samples were frozen out overnight using a refrigerator and then decanted into a test tube. Then, the samples were evaporated to dryness at $40{ }^{\circ} \mathrm{C}$ under a gentle stream of nitrogen. The residue was dissolved in 100 $\mu \mathrm{L}$ of acetonitrile/water 6:2 (V/V). Samples were briefly shaken and centrifuged for 5 minutes at 7'500 g. Supernatant was transferred into a glass vial. For sample work up of quercetin, $50 \mu \mathrm{L}$ of each plasma sample were pipetted into an Eppendorf tube. $5 \mu \mathrm{L}$ of internal standard solution $(0.05 \mathrm{ng} / \mu \mathrm{L}$ quercetin $\mathrm{d} 3$ in methanol/0.5 \% ascorbic acid $1: 1$ $(\mathrm{V} / \mathrm{V}))$ were added and the samples were briefly shaken. Then, $10 \mu \mathrm{L}$ sodium acetate solution $0.25 \%$ in methanol and $5 \mu \mathrm{L}$ glucuronidase solution (1:100 in water) were added. Samples were briefly shaken again and incubated for 5 hours at $40^{\circ} \mathrm{C}$. Subsequently, $10 \mu \mathrm{L} 1 \mathrm{~N} \mathrm{HCl}$ was added and samples were shaken briefly. After addition of 1.25 $\mathrm{mL}$ ethyl acetate, samples were shaken overhead for 10 minutes. The samples were centrifuged for 10 minutes at 7'500 $\mathrm{g}$ and frozen out overnight using a refrigerator. After, the supernatants were decanted into a test tube and evaporated to dryness at $40^{\circ} \mathrm{C}$ under a gentle stream of nitrogen. The residue was dissolved in $100 \mu \mathrm{L}$ methanol. Supernatant was transferred into a glass vial. To each sample, $50 \mu \mathrm{L}$ of $0.1 \%$ formic acid were added. Concentration of herbal marker in plasma was measured via UPLC MS/MS using same analytical methods as described for Caco-2 cell samples.

\section{Results}

\section{Solubility of naphthodianthrones was $\mathrm{pH}$-dependent}

The pH-dependent thermodynamic solubility of naphthodianthrones in SJW dry extract Ze 117 is outlined in Figure 2 and supplemental data A2. Hypericin exhibited $\mathrm{pH}$ dependence in its solubility profile with the lowest measured solubility at $\mathrm{pH} 1.2$. With a value of $23.78 \pm 0.43 \mu \mathrm{g} / \mathrm{mL}$, saturation solubility of hypericin at $\mathrm{pH} 6.8$ was about 5 -fold higher than the one at $\mathrm{pH} 1.2$, which showed a value of $4.61 \pm 0.03 \mu \mathrm{g} / \mathrm{mL}$. Same findings were evident for pseudohypericin, where the highest measured concentration of $9.84 \pm 0.07 \mu \mathrm{g} / \mathrm{mL}$ at $\mathrm{pH} 5.5$ was about 2.5 -fold higher than saturation solubility at $\mathrm{pH} 1.2$. In contrast to hypericin, the lowest concentration for pseudohypericin $(2.97 \pm 0.14$ $\mu \mathrm{g} / \mathrm{mL}$ ) was measured at $\mathrm{pH} 7.5$. Determined values after 48 hours were slightly lower than that measured after 24 hours except for maximum concentrations where no time dependent difference was evident.

\section{Solubility of flavonoids was not $\mathrm{pH}$-dependent}

Main flavonoids contained in SJW extract Ze 117 showed no $\mathrm{pH}$ dependence in their solubility profiles (Figure 2 and supplemental data Table A1, A2). Saturation concentration was between $4.56 \pm 0.06$ and $5.90 \pm 0.37 \mathrm{mg} / \mathrm{mL}$ for total flavonoids expressed as sum of rutin, hyperoside, isoquercitroside, quercitroside, quercetin and biapigenin. Single flavonoids exhibited saturation concentrations correlating to their amount in SJW extract. Main constituents were hyperoside and rutin followed by isoquercitroside and quercetin. Determined values after 48 hours were comparable to that measured after 24 hours.

\section{Hypericin showed low permeation through Caco-2 cell monolayers}

For permeation assessment of Ze 117, hypericin was used as surrogate for naphthodianthrones. Results are shown in Table 2. Hypericin as pure substance showed a $\mathrm{P}_{\text {app }}$ in ab direction of $3.19 \pm$ $0.72 \times 10-6 \mathrm{~cm} / \mathrm{s}$ confirming literature data $[25,26]$. Hypericin in the presence of quercetin showed an enhanced permeation with a $\mathrm{P}_{\text {app }}$ of $5.23 \pm 1.13 \times 10-6 \mathrm{~cm} / \mathrm{s}$. A permeation enhancement of hypericin through Caco-2 cell monolayers induced by the presence of flavonoids such as quercitrin was also found by Verjee [25]. Indeed, permeation of hypericin was observed to be lower when measured in the matrix of Ze 117. Here, $P_{\text {app }}$ value for ab permeation was $1.48 \pm 0.51 \times 10-6 \mathrm{~cm} / \mathrm{s}$. Hypericin as pure substance showed for permeation in ab and in ba direction similar $\mathrm{P}_{\text {app }}$ values. $\mathrm{P}_{\text {app }}$ value for ba permeation decreased in the presence of quercetin and additionally in a much higher extent, in the presence of Ze 117. Overall, determined $\mathrm{P}_{\text {app }}$ values for hypericin were comparable to that of low permeable reference substances (Figure 3). Efflux ratio of 0.94 for pure hypericin decreased markedly in presence of quercetin and $\mathrm{Ze} 117$, respectively. Comparing TEER values measured before and after performed Caco- 2 cell monolayer assay, presence of hypericin determined a significant decrease in cell monolayer integrity. A reduction in TEER values of approximately $25 \%$ was evident in Caco- 2 cells treated with pure hypericin. In presence of hypericin and quercetin, there was a $45 \%$ reduction and in presence of Ze 117, TEER values declined even by $63 \%$ (Figure 4 ). In contrast, TEER values were comparable before and after performed Caco-2 cell monolayer assay for Caco-2 cells treated with reference substances or quercetin as pure substance, respectively.

\section{Quercetin showed high permeation though Caco-2 cell monolayers}

Quercetin as marker for flavonoids in Ze 117 permeated through Caco- 2 cell monolayers with a $\mathrm{P}_{\text {app }}$ value of $33.76 \pm 5.35 \times 10-6 \mathrm{~cm} / \mathrm{s}$ in ab 

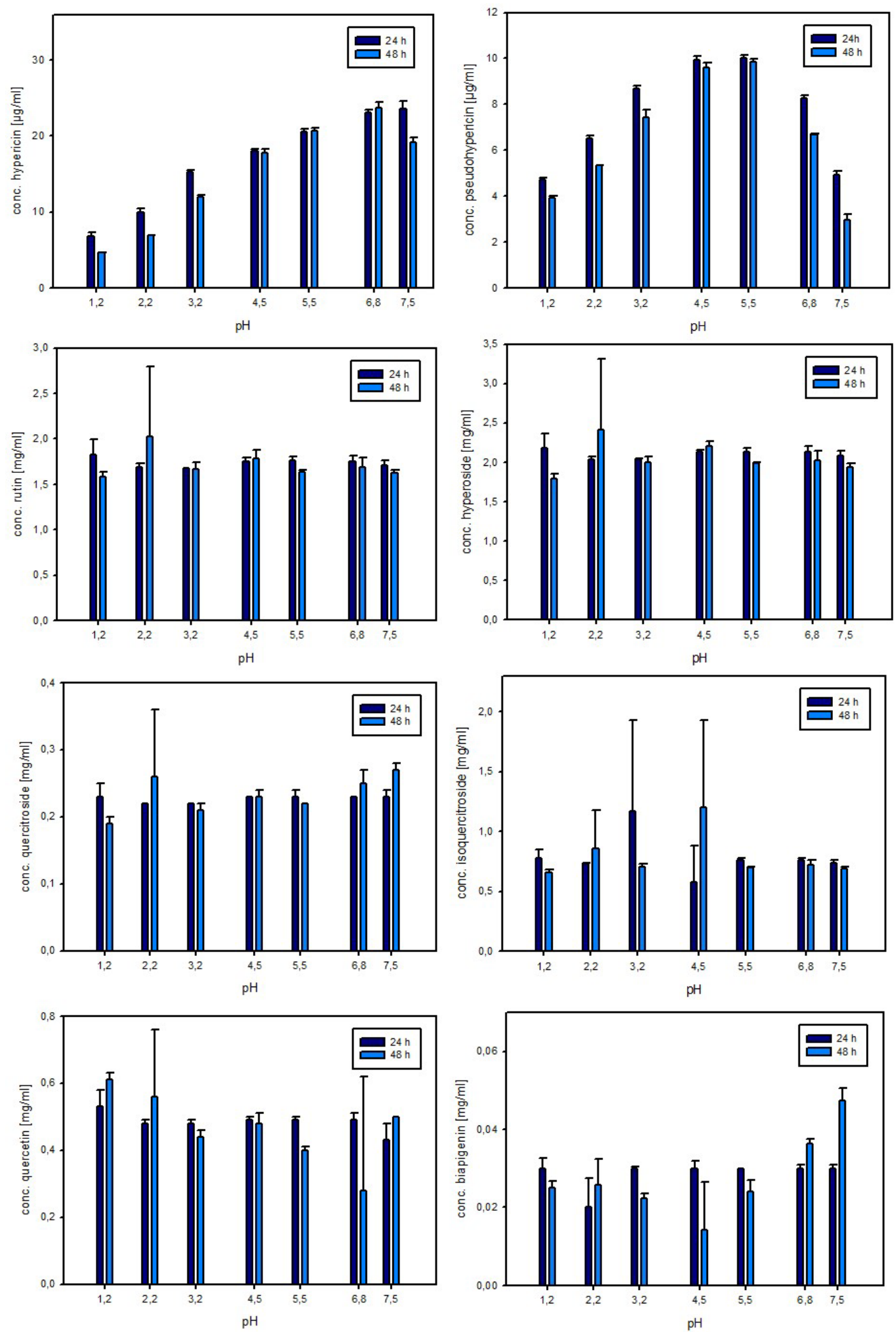

Figure 2: $\mathrm{pH}$-dependent solubility profile of hypericin and pseudohypericin calculated as hypericin as well as pH- dependent solubility profile of rutin, hyperoside, isoquercitroside, quercitroside, quercetin and biapigenin calculated as rutin in buffer media of different pH values after 24 hours and after 48 hours, values are given as average of saturation concentration $\pm \operatorname{SEM}(n=3)$. 
Citation: Disch L, Forsch K, Siewert B, Drewe J, Fricker G (2017) Sustained Release for St. John's Wort: A Rational Idea? J Bioequiv Availab 9: 565-576. doi: 10.4172/jbb. 1000363

\begin{tabular}{|c|c|c|c|c|c|c|c|}
\hline Substance & $\begin{array}{c}\mathbf{P}_{\text {app }} \mathbf{a b} \\
{\left[\mathbf{1 0}^{-6} \mathbf{c m} / \mathbf{s}\right]}\end{array}$ & $\begin{array}{c}\mathbf{P}_{\text {app }} \mathbf{b a} \\
{\left[\mathbf{1 0}^{-6} \mathbf{c m} / \mathbf{s}\right]}\end{array}$ & $\mathbf{R}_{\mathbf{M}} \mathbf{a b}$ & $\mathbf{R}_{\mathbf{M}}$ ba & $\mathbf{R}_{\mathbf{E}}$ & Permeated ab [\%] & Permeated ba [\%] \\
\hline FITC-dextran & $0.64 \pm 0.29$ & - & $1.13 \pm 0.06$ & - & - & $0.8 \pm 0.05$ \\
\hline Propranolol & $24.23 \pm 3.60$ & $34.13 \pm 1.62$ & $0.69 \pm 0.06$ & $1.12 \pm 0.04$ & $1.41 \pm 0.18$ & $27.4 \pm 3.56$ \\
\hline Metoprolol & $30.12 \pm 2.35$ & $33.64 \pm 1.74$ & $0.63 \pm 0.08$ & $1.08 \pm 0.03$ & $1.12 \pm 0.1$ & $30.6 \pm 1.45$ & $13.6 \pm 0.60$ \\
\hline Verapamil & $26.54 \pm 1.24$ & $36.30 \pm 1.58$ & $0.66 \pm 0.05$ & $1.16 \pm 0.04$ & $1.37 \pm 0.11$ & $28.4 \pm 0.01$ & $13.0 \pm 0.01$ \\
\hline Digoxin & $1.48 \pm 0.43$ & $21.28 \pm 2.16$ & $0.97 \pm 0.05$ & $0.93 \pm 0.03$ & $14.40 \pm 4.76$ & $1.3 \pm 0.23$ & $5.6 \pm 0.38$ \\
\hline Furosemide & $0.99 \pm 0.23$ & $6.67 \pm 0.34$ & $0.59 \pm 0.01$ & $0.64 \pm 0.01$ & $6.73 \pm 1.27$ & $0.8 \pm 0.00$ & $2.1 \pm 0.00$ \\
\hline Hydrochlorothiazide & $1.16 \pm 0.04$ & $1.29 \pm 0.02$ & $0.67 \pm 0.02$ & $0.68 \pm 0.01$ & $1.11 \pm 0.04$ & $0.7 \pm 0.00$ & $0.4 \pm 0.00$ \\
\hline $\begin{array}{c}\text { Hypericin pure } \\
\text { Hypericin in presence } \\
\text { of quercetin }\end{array}$ & $3.19 \pm 0.72$ & $3.00 \pm 1.47$ & $0.89 \pm 0.08$ & $0.68 \pm 0.04$ & $0.94 \pm 1.28$ & $8.3 \pm 1.67$ & $0.8 \pm 0.31$ \\
\hline $\begin{array}{c}\text { Hypericin in matrix of } \\
\text { Ze 117 }\end{array}$ & $1.48 \pm 0.51$ & $0.35 \pm 0.07$ & $0.63 \pm 0.05$ & $1.10 \pm 0.10$ & $0.24 \pm 0.27$ & $1.2 \pm 0.32$ & $0.1 \pm 0.02$ \\
\hline $\begin{array}{c}\text { Quercetin pure } \\
\text { Quercetin in presence } \\
\text { of hypericin }\end{array}$ & $29.38 \pm 11.76 \pm 5.35$ & $33.29 \pm 6.76$ & $0.83 \pm 0.18$ & $0.90 \pm 0.16$ & $0.99 \pm 0.26$ & $21.0 \pm 2.97$ & $11.6 \pm 2.06$ \\
\hline $\begin{array}{c}\text { Quercetin in matrix of } \\
\text { Ze 117 }\end{array}$ & $26.30 \pm 8.95$ & $27.62 \pm 6.70$ & $0.86 \pm 0.17$ & $0.88 \pm 0.13$ & $1.05 \pm 0.14$ & $28.1 \pm 13.46$ & $7.7 \pm 1.76$ \\
\hline
\end{tabular}

Table 2: Apparent permeability $P_{\text {app }}$, recovery rate $R_{M}$, efflux ratio $R_{E}$ and amount of permeated substance through Caco- 2 cell monolayer after 180 min in ab and ba directions $(n=6)$, values are given as average \pm SEM.

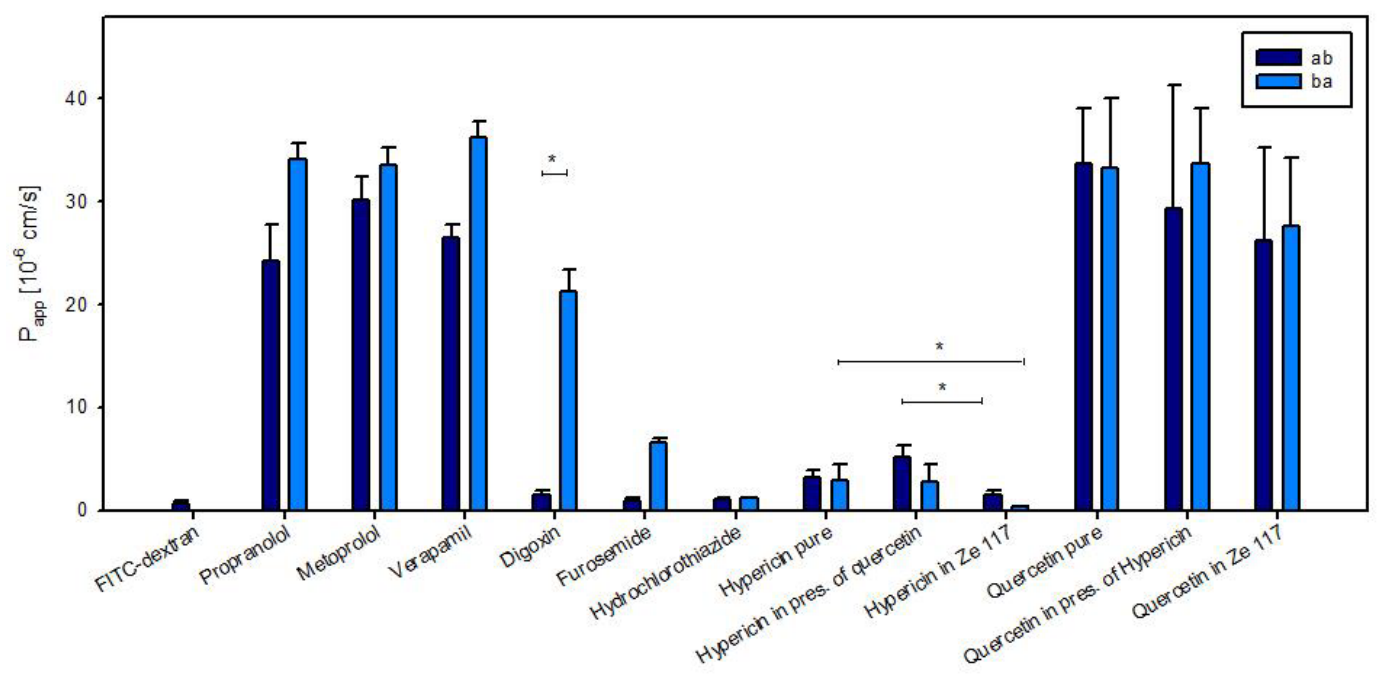

Figure 3: Apparent permeability $P_{\text {app }}$ of reference substances as well as hypericin and quercetin as analytical marker substances of Ze 117 through Caco-2 cell monolayers in ab and ba directions, values are given as average \pm SEM $(n=6-9)$, significance is indicated by asterisk $p<0.05$.

direction (Figure 3 and Table 2). Permeation differed not significantly in the presence of hypericin and Ze 117, respectively. Permeation in ba direction was similar to $\mathrm{P}_{\text {app }}$ values of ab permeation and independent of quercetin and St. John's wort extract Ze 117. Overall, determined $\mathrm{P}_{\text {app }}$ values for quercetin were comparable to that of high permeable reference substances. Efflux ratio was found to be between 0.99 and 1.15 (Figure A3).

\section{Hypericin was absorbed in situ mainly in jejunum}

Absorption of naphtodianthrones expressed as sum of hypericin and pseudohypericin exhibited great differences between duodenum, jejunum, ileum and colon (Table 3 and Figure 5). There was an evident absorption in upper intestine that decreased significantly the lower the intestinal region. Administration of Ze 117 extract solution into duodenum resulted in the highest plasma levels of hypericin and pseudohypericin. Plasma concentration showed delayed absorption with maxima after two hours, what correlates with information in HMPC monograph [4]. Plasma AUC of the two naphtodianthrones after jejunal absorption amounted approximately $60-70 \%$ of that of duodenal absorption. In contrast to duodenal absorption, in jejunum there was no delayed absorption evident. Even after 30 minutes there were naphtodianthrone concentrations detectable in plasma samples. In ileum and colon, there was nearly no absorption of naphtodianthrones. Plasma profiles varied proportional to the dose. Determined plasma concentrations were correlated to 3 hours measurement in intestinal segment each ligated for the same length. As both length of intestinal segments and transit times differ in vivo, measured absorption capacity had to be corrected by taking into account physiological conditions. Table 4 lists human intestinal transit times and length of single intestinal segments according GastroPlus ${ }^{\mathrm{TM}}$ software. Calculated AUC for each intestinal segment was related to appropriate human length and transit time and termed as $\mathrm{AUC}_{\text {phys }}$ (Figure A3). With correlation 
Citation: Disch L, Forsch K, Siewert B, Drewe J, Fricker G (2017) Sustained Release for St. John's Wort: A Rational Idea? J Bioequiv Availab 9: 565-576. doi: $10.4172 / \mathrm{jbb} .1000363$

$a b$

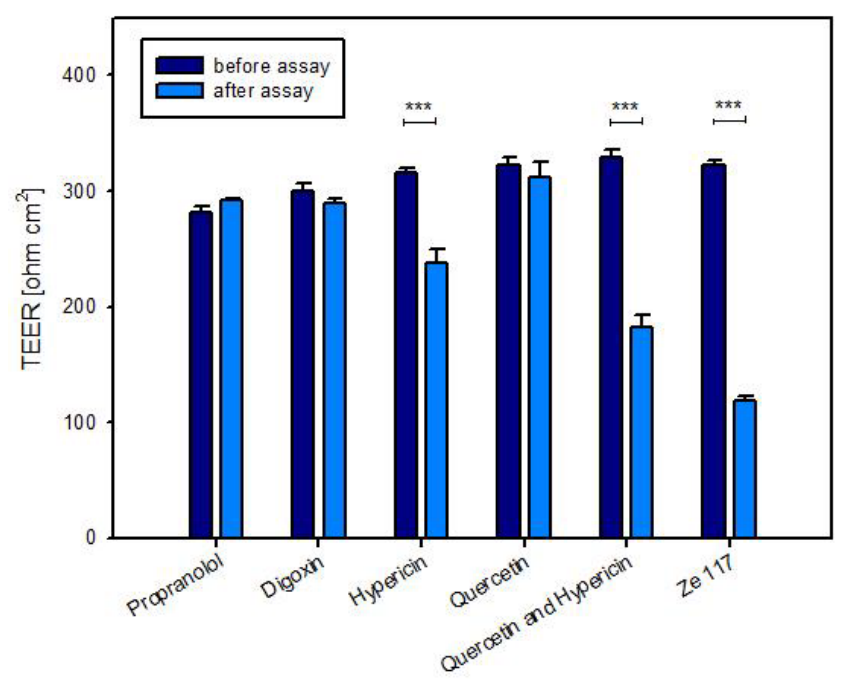

Figure 4: TEER values of Caco-2 cell monolayers after treatment with reference substances, hypericin and quercetin as pure substances and Ze 117, values given as mean \pm SEM $(n=6-9)$, significance is indicated by asterisk $p<0.001$.
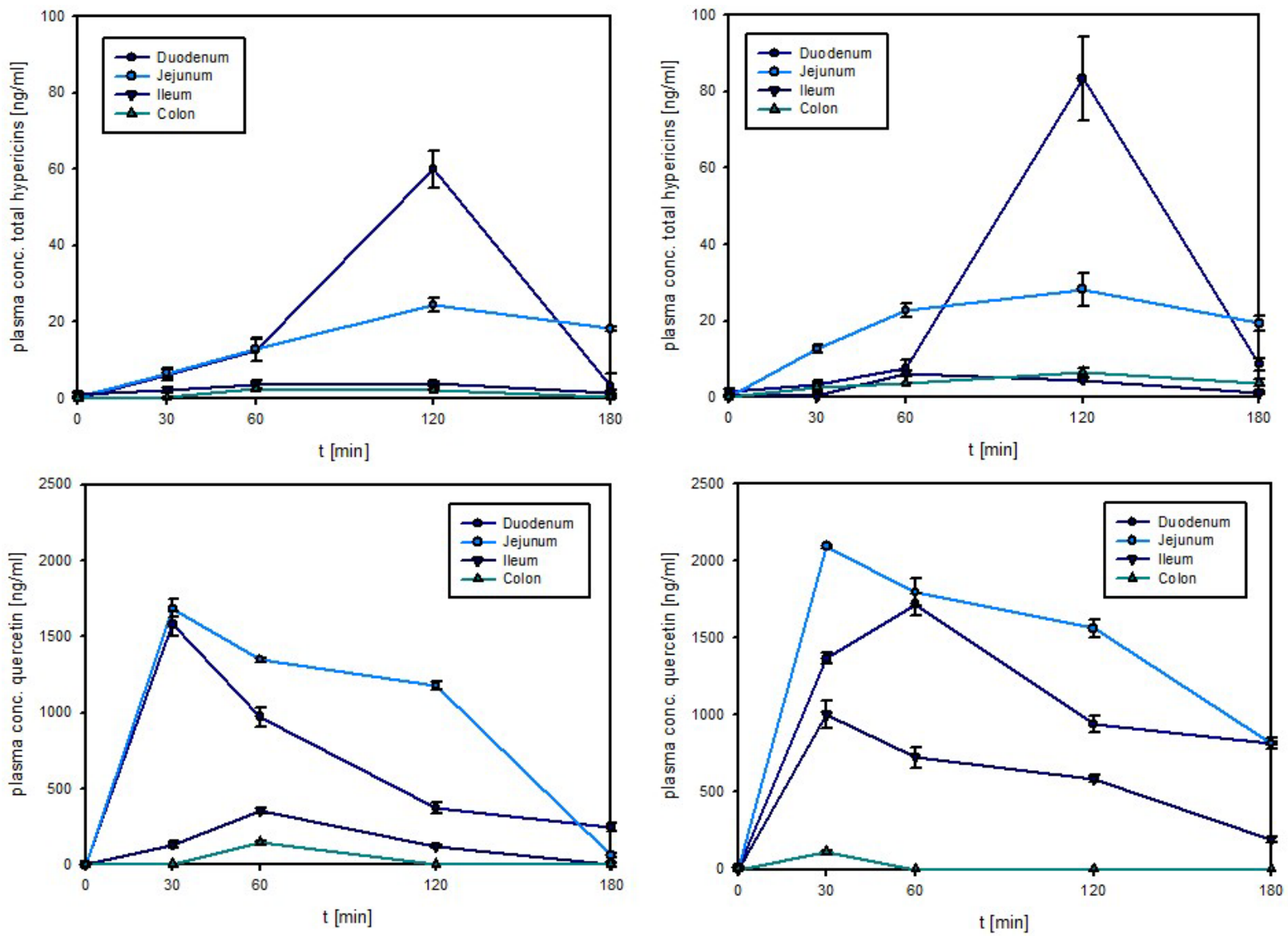

Figure 5: Plasma profiles as sum of hypericin and pseudohypericin calculated as hypericin (overhead) as well as sum of quercetin (beneath) after intestinal administration of Ze 117 in doses of $37.5 \mathrm{mg} / \mathrm{kg}$ rat body weight in addition of hypericin corresponding to $5.0 \mathrm{mg} / \mathrm{kg}$ (left) and administration of Ze 117 in doses of $75.0 \mathrm{mg} / \mathrm{kg}$ rat body weight in addition of hypericin corresponding to $10.0 \mathrm{mg} / \mathrm{kg}$ (right), values given as mean \pm SEM ( $\mathrm{n}=3-4)$. 
of measured AUC for hypericin in rat plasma with human intestinal length and transit times, duodenum showed lowest absorption capacity as length and transit time are relatively short compared to other intestinal segments. Highest absorption capacity was calculated for ileum. Also for ileum and colon, absorption capacity was evident that was calculated to be a third of that in jejunum.

\section{Quercetin was absorbed in situ mainly in small intestine}

Quercetin was measured in plasma samples as surrogate for flavonoids contained in Ze 117. Highest AUC of quercetin was found after administration of Ze 117 extract solution into jejunum followed by that in duodenum (Figure 5 and Table 3). Administration into ileum resulted in markedly lower plasma levels whereas nearly no absorption of quercetin was found in colon. Absorption maxima were between 30 and 60 minutes. Plasma profiles varied proportional to the dose. Metabolites of quercetin such as tamarixetin and isorhamnetin were not found in plasma samples. Taking into account both length of intestinal segments and transit times, duodenum and colon showed very low absorption capacity for quercetin. Best performance regarding quercetin absorption was calculated for jejunum followed by ileum (Table 4 and Figure A3).

\section{Discussion}

For a solid drug substance, release out of the dosage form (liberation) is crucial prior to absorption in human gastro intestinal tract. Sustained release dosage forms exhibit slow drug release with controlled dissolution profiles. Here, dissolution is the rate-determining step in absorption. Nevertheless, drug solubility in aqueous media presents an important physicochemical parameter for selection of a suitable sustained release system. Over a physiological $\mathrm{pH}$ range, $\mathrm{pH}$-dependent thermodynamic solubility of naphthodianthrones and flavonoids contained in SJW extract Ze 117 was determined. Both regarded naphtodianthrones hypericin and pseudohypericin showed $\mathrm{pH}$-dependence in their solubility profiles with highest measured concentration at $\mathrm{pH} 6.8$ for hypericin and $\mathrm{pH} 5.5$ for pseudohypericin. Solubility at acidic $\mathrm{pH}$ values was much lower for both naphtodianthrones. High concentration of protons in acidic media may determine protonation of hypericin at a carbonyl group and thus, change of the chromophoric properties [26,27]. At basic $\mathrm{pH}$ values, a deprotonation of a hydroxyl group may lead to an analogous effect. pKa values of hypericin are 2 and 11 [27]. The large conjugated system of hypericin leads to good stabilization of positive or negative charging. An accompanied change in absorption maximum may result in lower concentrations measured at predetermined detection wavelength [28]. Same consideration applied to pseudohypericin. Indeed, lowest solubility for pseudohypericin was at $\mathrm{pH}$ 7.5. corresponding to $\mathrm{pKa}$ value of 7.2 [29]. Furthermore, naphthodianthrones form with the large conjugated system insoluble aggregates in aqueous solutions [30]. These stacking aggregates may result in low aqueous solubility. Solubility of pure hypericin in water is increased by some phenolic constituents typical for SJW extracts [11]. As pH-dependent thermodynamic solubility was determined for hypericin and pseudohypericin in the matrix of Ze 117, other constituents may influence solubility of hypericin and pseudohypericin in a positive way. Lowest measured saturation solubility for hypericin was $4.61 \pm 0.03 \mu \mathrm{g} / \mathrm{mL}$ at $\mathrm{pH} 1.2$, whereas for pseudohypericin lowest value was $2.97 \pm 0.14 \mu \mathrm{g} / \mathrm{mL}$ at $\mathrm{pH}$ 7.5. Overall, determined saturation solubility of hypericin was higher than that of pseudohypericin. SJW extracts of European origin exhibit characteristic pseudohypericin hypericin ratios of 1.5-2:1 as pseudohypericin exhibiting higher hydrophilicity than hypericin and is extracted in a higher quantity

\begin{tabular}{|c|c|c|c|c|c|}
\hline \multirow{2}{*}{ Analytical markers } & \multirow{2}{*}{ Dose administered } & \multirow{2}{*}{ Intestinal segment } & \multicolumn{3}{|c|}{ PK parameters } \\
\hline & & & $T_{\max }[\min ]$ & $C_{\max }[\mathrm{ng} / \mathrm{mL}]$ & AUC $[\mu \mathrm{g} \mathrm{min} / \mathrm{mL}]$ \\
\hline \multirow{4}{*}{$\begin{array}{l}\text { Hypericin, pseudo- } \\
\text { hypericin }\end{array}$} & \multirow{4}{*}{$\begin{array}{c}37.5 \mathrm{mg} / \mathrm{kg} \\
\mathrm{Ze} 117\end{array}$} & duodenum & 120 & $59.99 \pm 4.86$ & $4.78 \pm 0.46$ \\
\hline & & jejunum & 120 & $24.40 \pm 1.84$ & $2.79 \pm 0.29$ \\
\hline & & Ileum & 120 & $3.90 \pm 0.56$ & $0.52 \pm 0.07$ \\
\hline & & Colon & 60 & $2.40 \pm 0.05$ & $0.25 \pm 0.01$ \\
\hline \multirow{4}{*}{$\begin{array}{l}\text { Hypericin, pseudo- } \\
\text { hypericin }\end{array}$} & \multirow{4}{*}{$\begin{array}{c}75.0 \mathrm{mg} / \mathrm{kg} \\
\text { Ze } 117\end{array}$} & duodenum & 120 & $83.40 \pm 11.01$ & $5.51 \pm 0.63$ \\
\hline & & jejunum & 120 & $28.20 \pm 4.32$ & $4.00 \pm 0.27$ \\
\hline & & Ileum & 60 & $6.20 \pm 0.70$ & $0.59 \pm 0.03$ \\
\hline & & Colon & 120 & $6.40 \pm 1.25$ & $0.73 \pm 0.02$ \\
\hline \multirow{4}{*}{ Quercetin } & \multirow{4}{*}{$\begin{array}{c}37.5 \mathrm{mg} / \mathrm{kg} \\
\mathrm{Ze} 117\end{array}$} & duodenum & 30 & $1 ’ 581.70 \pm 79.77$ & $121.09 \pm 2.21$ \\
\hline & & jejunum & 30 & $1^{\prime} 684.40 \pm 58.80$ & $185.56 \pm 2.20$ \\
\hline & & Ileum & 60 & $355.10 \pm 19.27$ & $27.13 \pm 1.54$ \\
\hline & & Colon & 60 & $146.40 \pm 13.89$ & $3.28 \pm 0.45$ \\
\hline \multirow{4}{*}{ Quercetin } & \multirow{4}{*}{$\begin{array}{c}75.0 \mathrm{mg} / \mathrm{kg} \\
\mathrm{Ze} 117\end{array}$} & duodenum & 60 & $1716.80 \pm 69.78$ & $199.06 \pm 5.75$ \\
\hline & & jejunum & 30 & $2 \prime 091.50 \pm 10.72$ & $261.69 \pm 5.74$ \\
\hline & & Ileum & 30 & $1^{\prime} 003.00 \pm 91.23$ & $103.69 \pm 3.02$ \\
\hline & & Colon & 30 & $109.26 \pm 14.86$ & $6.59 \pm 0.63$ \\
\hline
\end{tabular}

Table 3: $T_{\max }, C_{\max }$ and AUC of hypericin and quercetin in plasma samples obtained from in-vivo study, values are given as average \pm SEM $(n=4)$.

\begin{tabular}{|c|c|c|c|c|c|c|}
\hline \multirow[t]{2}{*}{$\begin{array}{c}\text { Intestinal } \\
\text { segment }\end{array}$} & \multirow[t]{2}{*}{$\begin{array}{c}\text { Transit time } \\
\text { [h] }\end{array}$} & \multirow[t]{2}{*}{ Length $[\mathrm{cm}]$} & \multicolumn{2}{|c|}{$\begin{array}{l}\mathrm{AUC}_{\text {phys }} \text { naphthodianthrones }[\mu \mathrm{g} \mathrm{min} / \mathrm{mL} \text { ] (AUC related to } \\
\text { appropriate human length and transit time) }\end{array}$} & \multicolumn{2}{|c|}{$\begin{array}{l}\text { AUC } \\
\text { (AUy) } \text { relaercetin [mg min } / \mathrm{mL}] \\
\text { length and transit time) }\end{array}$} \\
\hline & & & $13.4 \mathrm{mg} / \mathrm{kg}$ Ze 450 & $26.8 \mathrm{mg} / \mathrm{kg} \mathrm{Ze} 450$ & $13.4 \mathrm{mg} / \mathrm{kg} \mathrm{Ze} 450$ & $26.8 \mathrm{mg} / \mathrm{kg} \mathrm{Ze} 450$ \\
\hline duodenum & 0.3 & 14 & $6.69 \pm 0.64$ & $7.72 \pm 0.89$ & $0.17 \pm 0.00$ & $0.28 \pm 0.01$ \\
\hline jejunum & 1.7 & 116 & $183.40 \pm 18.94$ & $262.68 \pm 18.06$ & $12.2 \pm 0.14$ & $17.20 \pm 0.38$ \\
\hline ileum & 1.3 & 174 & $39.23 \pm 4.99$ & $44.37 \pm 1.89$ & $2.05 \pm 0.12$ & $7.82 \pm 0.23$ \\
\hline ascending colon & 12.6 & 28 & $29.58 \pm 1.30$ & $86.22 \pm 2.68$ & $0.39 \pm 0.05$ & $0.77 \pm 0.07$ \\
\hline
\end{tabular}

Table 4: AUC of naphthodianthrones hypericin and pseudohypericin in plasma and AUC of quercetin in plasma related to human transit time and intestinal length. 
by using extraction solvent of ethanol water mixtures [31]. However, results of $\mathrm{pH}$-dependent solubility study did not reflect this pseudohypericin hypericin ratio. Obviously, constituents of Ze 117 influence solubility of hypericin and that of pseudohypericin in a different manner. When evaluated according to class boundaries of FDA Guidance for Industry "Waiver of in vivo bioavailability and bioequivalence studies for immediate-release solid oral dosage forms based on a Biopharmaceutics Classification System (BCS)" [32], criteria "highly soluble" is fulfilled if the highest dose strength is soluble in less than $250 \mathrm{~mL}$ buffer over a $\mathrm{pH}$ range of 1 to 7.5 . With regard to the lowest determined saturation concentration, hypericin can be regarded as "highly soluble" up to maximal dose strength of $1.15 \mathrm{mg}$ according BCS. The "highly soluble" limit for pseudohypericin was calculated to be $0.74 \mathrm{mg}$. Compared to the drug product Remotiv 250 (Max Zeller Söhne AG, Romanshorn, Switzerland) containing $250 \mathrm{mg}$ SJW dry extract $\mathrm{Ze} 117$ and a total content of hypericin and pseudohypericin in the range of $0.1-0.3 \%$ (corresponding to $0.25-0.75 \mathrm{mg}$ ), both naphthodianthrones can be regarded as highly soluble substances according BCS. However, there is not a large margin between determined "highly soluble" limit and single dose concentration of naphthodianthrones. If compared to the drug product Remotiv" 500 (Max Zeller Söhne AG, Romanshorn, Switzerland) containing $500 \mathrm{mg}$ SJW dry extract Ze 117, pseudohypericin has to be classified as "low soluble" substance according BCS criteria. However, low solubility resulting of a closed in vitro system has a merely limited prediction for in vivo performance. As in vivo, concentration of solute drug is decreased continuously by absorption, reaching of saturation solubility in the intestinal tract is not presumable. Based on the results for $\mathrm{pH}$ dependent thermodynamic solubility of naphtodianthrones, there was no indication for difference in in vivo performance of Remotiv 250 and Remotiv 500. Hypericin as marker for naphthodianthrones in Ze 117 showed a low permeation when investigated using Caco2 cell monolayers. Presence of quercetin resulted in an enhanced ab permeation and a slightly decreased ba permeation of hypericin. $\mathrm{Ze}$ 117 seemed to influence both $\mathrm{ab}$ and ba permeation of hypericin in a negative way. Interaction with efflux transporter proteins such as $\mathrm{P}$-glycoprotein (P-gp) was not indicated as permeation in ab direction was higher than that in ba direction. As $\mathrm{P}_{\text {app }}$ values observed for hypericin were comparable to that of reference substances with low permeation, hypericin can be regarded as low permeable substance and was classified as BCS II substance. Comparison of pure hypericin with performance in presence of quercetin and extract matrix of SJW extract Ze 117, respectively, was determined within the same concentration ranges for hypericin to ensure comparability of results. Considering measured TEER values of Caco- 2 cell monolayers treated with hypericin, a decrease was evident. Observed reduction in TEER values indicated a loss of Caco- 2 cell monolayer integrity. Probably, used hypericin concentration compromised cell viability and Caco-2 cell monolayers treated with lower hypericin concentrations may show more descriptive results. TEER measurement of Caco- 2 cell monolayers treated with $\mathrm{Ze} 117$ showed lowest values after the assay, matrix of $\mathrm{Ze}$ 117 seemed to intensify cell viability impairment caused by hypericin. In this study, hypericin concentration was selected based on the analytical limit of quantification. For lower hypericin concentrations than used, there was no permeation detectable especially in acceptor compartments at the beginning of the assay. Low TEER values indicate impairment of cell monolayers. A non-sufficient monolayer integrity may result in overestimation of permeability. In fact, determined $P_{\text {app }}$ values were higher than they should be. Mass transfer of hypericin over 3 hours showed linear progression, so significant increase of hypericin permeation during the assay was not evident. This finding encourages sufficient Caco-2 monolayer integrity despite of decreasing TEER values. A general minimum limit of TEER indicating a nonsufficient cell monolayer integrity is hard to determine as TEER values vary depending on used equipment [33] and other factors such as temperature and used media [34]. In addition, decrease in TEER is proportional with an increased electron flux through cell monolayers. As electrons are much smaller than drug molecules, decreasing TEER values do not correlate proportionally to cell monolayer permeability for drug molecules and drug substance flux. However, an overestimation of permeation would not change BCS classification. Hypericin is still classified as low permeable substance even when exhibiting lower $\mathrm{P}_{\text {app }}$ values.

Assessing flavonoids in Ze 117, thermodynamic solubility for rutin, hyperoside, isoquercitroside, quercitroside, quercetin and biapigenin exhibited no $\mathrm{pH}$ - dependence. According BCS criteria, flavonoids can be regarded as "highly soluble" up to maximal dose strength of 1.14 g. As products of SJW such as Remotiv" 250 and Remotiv" 500 contain single doses of SJW dry extract Ze 117 of $250 \mathrm{mg}$ and $500 \mathrm{mg}$, respectively, flavonoids can be classified generally as "highly soluble". Quercetin as marker for flavonoids in Ze 117 showed a high permeation when investigated using Caco-2 cell monolayers. Based on the findings, quercetin could be classified into BCS class I. Interaction with efflux transporter proteins such as $\mathrm{P}$ glycoprotein (P-gp) was not indicated. However, for highly permeable substances identification of efflux transporter substrates is hard to determine as high passive diffusion would not be altered significantly by active efflux transporters. To identify efflux transporter substrates, presence of an efflux transporter inhibitor is needed during Caco-2 cell monolayer assay.

Permeation of several reference substances measured through Caco-2 cell monolayers exhibited a good in vitro in vivo correlation [35]. However, Caco-2 cell assay results of hypericin and quercetin in SJW extract Ze 117 admit just an estimation about the extent of absorption. No prediction of absorption performance of different intestinal segments could be done. For sustained release dosage forms, a continuous drug absorption along the whole intestine is necessary for most systems. To evaluate the absorption performance of hypericin and quercetin in Ze 117 in dependence of intestinal regions, an in situ study was performed in rat. Hence, the aim was to compare local absorption capacity of different intestinal segments in order to identify possible absorption windows and determine a rational timeline for drug release. Results showed the highest absorption capacity of hypericin after administration of $\mathrm{Ze} 117$ in jejunum. Significantly lower performance was found after administration in duodenum, ileum and colon. Furthermore, a delayed absorption with maximal plasma concentration of hypericin after 2 hours was obvious in rat duodenum. As human transit time in duodenum is assumed to be 0.3 hours at the mean, duodenal absorption processes are rather irrelevant for naphthodianthrones. For most SR formulations, drug absorption along the whole intestinal tract is an important requirement for proper performance of the delivery system. If there is sufficient in vivo absorption capacity for hypericin along human ileum and colon when drug is released out of a SR system, could be answered best by a pharmacokinetic in vivo study in humans. Quercetin was found to be absorbed mainly in small intestine, whereas highest absorption capacity was found after administration of Ze 117 into jejunum followed by that into ileum. Duodenum showed a low absorption capacity as length and transit time are relatively short compared to other intestinal segments. In colon, there was nearly no absorption of quercetin. With regard to the large microbial system present in colon [36], there is the possibility that quercetin underwent microbial metabolism in a faster way than 
absorption processes took place. Metabolites were assumed to be small unspecific molecules such as phloroglucinol and acid derivatives [37] or carbon dioxide [38]. As plasma samples were not screened for these metabolites, low absorption capacity of quercetin could also have traced back to the comparably low surface area in colon. If so, quercetin is not suitable as analytical marker for sustained release formulations with drug release over the whole intestinal tract including colon. Without the assumption of metabolism, for quercetin as marker for flavonoids, results indicate an absorption window in small intestine, mainly in jejunum. Considering human intestinal transit times for small intestinal tract, dissolution profile target of $80 \%$ drug release within 8 hours is reasonable. This target ensures reproducible release and absorption of the majority of drug substance.

Dissolution target profiles with drug release longer than 8 hours demand for hydrodynamic systems (floating systems) that float over the gastric content for a prolonged period of time [39] while drug release. The active substance is secreted this way into small intestine continuously, where absorption processes can take place. As a high concentration of excipients is needed for hydrodynamically systems, the technology is suitable just for low drug loads. For SJW with a daily dose of $500 \mathrm{mg}$ Ze 117, hydrodynamically systems are considered to be not suitable. Therefore, dissolution target of sustained drug release within 8 hours is rational.

Depending on components in SJW extract exhibiting physicochemical different properties and the high drug load of $500 \mathrm{mg}$ Ze 117 per daily dose, selection of a suitable sustained release system is challenging. Type and amount of excipients are limited. Synchronous release of all extract components is preferable as changing the relative ratio of components may result in an alteration of pharmacological activity. Sustained release products are desired to prolong drug release without alteration of pharmacological properties. For achieving synchronous release, excipients must not interact physicochemically with any extract compound. When selecting hydrophobic matrix delivery systems, there is the possibility for low soluble lipophilic extract compounds to remain in the hydrophobic matrix excipient. This results in insufficient release of these compounds and a nonsynchronous release compared to high soluble hydrophilic extract compounds. Same risk applies for SR reservoir delivery systems, where lipophilic substances may permeate insufficiently through the SR coating polymer but cumulate on the coating material. Solution of drug inside of reservoir delivery systems is key for permeation through functional coating materials. That is a requirement what is critical especially for low soluble extract compounds. Best option to achieve synchronic release is to formulate SJW extract into a twochamber osmotic push pull system. But as these systems are high in cost of production, it would not be first choice. Another possibility provides a hydrophilic matrix delivery system. Here, drug release relies mainly on erosion of matrix excipients what ensures a complete drug release covering all extract compounds. Both systems need a certain amount of excipients what is restricted by the high drug load of SJW extract. Pharmaceutical formulation development is needed for reliable feasibility evaluation.

For development of a SJW sustained release formulation, dissolution profiles would be optimized on analytical marker to represent the whole extract. As SJW extract is classified as quantified extract according EP, focus on analytical marker is just an approximation of sustained release properties of the dosage form. In vitro testing of analytical marker provides just an assumption on how the whole extract performs in vivo. Development of a sustained release drug product of SJW extract is due to the discussed points a very challenging assignment and has to be carefully considered.

\section{Conclusion}

Development of a sustained release formulation for SJW extract is challenging due to the high drug load and the complex mixture of SJW extract covering a range of substances with different physicochemical properties and pharmacological activities. Additionally, presence of an absorption window in small intestine, mainly in jejunum was found for analytical marker. Selection of a suitable sustained release formulation is time and cost consuming. As SJW extract is classified as quantified extract according EP, in vitro testing of selected analytical marker provides just an assumption on how the whole extract performs in vivo. Suitability of SJW extract to be formulated into a SR delivery system is restricted. Further evaluation by formulation studies and clinical studies are necessary.

\section{Acknowledgement}

We gratefully thank Pia Müller, Christin Jensbach and Peter Zimmermann for the opportunity to use LC-MS/MS equipment of Takeda $\mathrm{GmbH}$ in Singen (Germany) and their assistance in data acquisition. In addition, we thank Thomas Lange for his support in method set up and data interpretation. The studies were supported financially by Max Zeller Söhne AG (Romanshorn, Switzerland).

\section{References}

1. Kumar KPS, Bhowmik D, Chandira CM, Tripathi KK (2010) Innovations in Sustained Release Drug Delivery System and its Market Opportunities. J Chem Pharm Res 2: 346-360.

2. Apaydin EA, Maher AR, Shanman R, Booth MS, Miles JN et al. (2016) A systematic review of St. John's wort for major depressive disorder. Syst Rev 5: 148.

3. Posadzki P, Watson LK, Ernst E (2013) Adverse effects of herbal medicines: an overview of systematic reviews. Clin Med (Lond) 13: 7-12.

4. HMPC (2009) Community Herbal Monograph on Hypericum perforatum L., Herba (well-established medicinal use). Commitee on Herbal Medicinal Products (HMPC). European Medicines Agency (EMA)

5. Butterweck V, Schmidt M (2007) St. John's wort: role of active compounds for its mechanism of action and efficacy. Wien Med Wochenschr 157: 356-361.

6. Zobayed SM, Afreen F, Goto E, Kozai T (2006) Plant-environment interactions Accumulation of hypericin in dark glands of Hypericum perforatum. Ann Bot 98: 793-804

7. Soelberg J, Jorgensen LB, Jager AK (2007) Hyperforin accumulates in the translucent glands of Hypericum perforatum. Ann Bot 99 1097-1100.

8. Milevskaya VV, Statkus MA, Temerdashev ZA, Kiseleva NV, Butyl'skaya TS et al.(2016) Extraction and determination of biologically active components of St. John's wort and its pharmaceutical preparations. J Anal Chem 71: 741.

9. Chang Y, and Wang SJ (2010) Hypericin, the active component of St. John's wort inhibits glutamate release in the rat cerebrocortical synaptosomes via a mitogenactivated protein kinase-dependent pathway. Eur J Pharmacol 634: 53-61.

10. Zhai XJ, Chen F, Chen C, Zhu CR, Lu YN (2015) LC-MS/MS based studies on the anti-depressant effect of hypericin in the chronic unpredictable mild stress rat model. J Ethnopharmacol 169 363-369.

11. 11. Jürgenliemk $G$, Nahrstedt $A$ (2003) Dissolution, solubility and cooperativity of phenolic compounds from Hypericum perforatum $L$. in aqueous systems Pharmazie 58: 200-203.

12. Butterweck V, Korte B, Winterhoff H (2001) Pharmacological and endocrine effects of Hypericum perforatum and hypericin after repeated treatment. Pharmacopsychiatry 34 Suppl 1: S2-7

13. Noldner, M, and Schotz, K (2002) Rutin is essential for the antidepressant activity of Hypericum perforatum extracts in the forced swimming test. Planta Med 68: 577-580

14. Haas JS, Stolz ED, Betti AH, Stein AC, Schripsema J, et al. (2011) The antiimmobility effect of hyperoside on the forced swimming test in rats is mediated by the D2-like receptors activation. Planta Med 77: 334-339. 
Citation: Disch L, Forsch K, Siewert B, Drewe J, Fricker G (2017) Sustained Release for St. John's Wort: A Rational Idea? J Bioequiv Availab 9: 565-576. doi: 10.4172/jbb. 1000363

15. Wurglics M, Schubert-Zsilavecz M (2006) Hypericum perforatum: a 'modern' herbal antidepressant: pharmacokinetics of active ingredients. Clin Pharmacokinet 45: 449-468.

16. Moore LB, Goodwin B, Jones SA, Wisely GB, Serabjit-Singh CJ, Willson TM Collins JL, Kliewer SA (2000) St. John's wort induces hepatic drug metabolism through activation of the pregnane $X$ receptor. Proc Natl Acad Sci 97: 75007502 .

17. Mueller SC, Majcher-Peszynska J, Mundkowski RG, Uehleke B, Klammt S, et al. (2009) No clinically relevant CYP3A induction after St. John's wort with low hyperforin content in healthy volunteers. Eur J Clin Pharmacol 65: 81-87.

18. Whitten, DL, Myers, SP, Hawrelak, JA, Wohlmuth, H (2006) The effect of St John's wort extracts on CYP3A: a systematic review of prospective clinical trials. Br J Clin Pharmacol 62: 512-526.

19. Mai I, Bauer S, Perloff ES, Johne A, Uehleke B, Frank B, Budde K, Roots I (2004) Hyperforin content determines the magnitude of the St John's wortcyclosporine drug interaction. Clin Pharmacol Ther 76: 330-340.

20. Will-Shahab L, Bauer S, Kunter U, Roots I, Brattström A (2008) St John's wort extract (Ze 117) does not alter the pharmacokinetics of a low-dose oral contraceptive. Eur J Clin Pharmacol 65: 287-294.

21. Schulz HU, Schurer M, Bassler D, Weiser D (2005) Investigation of pharmacokinetic data of hypericin, pseudohypericin, hyperforin and the flavonoids quercetin and isorhamnetin revealed from single and multiple oral dose studies with a hypericum extract containing tablet in healthy male volunteers. Arzneimittelforschung 55: 561-568.

22. Brockmöller J, Reum T, Bauer S, Kerb R, Hubner WD, Roots I (1997) Hypericin and pseudohypericin: pharmacokinetics and effects on photosensitivity in humans. Pharmacopsychiatry 30 Suppl 2: 94-101.

23. Mishra DS, Yalkowsky SH (1992) Ideal solubility of a solid solute: effect of heat capacity assumptions. Pharm Res 9: 958-959.

24. Artursson P, Palm K, Luthman K (2001) Caco-2 monolayers in experimenta and theoretical predictions of drug transport. Adv Drug Deliv Rev 46: 27-43.

25. Verjee S, Brugger D, Abdel-Aziz H, Butterweck V (2015) Permeation Characteristics of Hypericin across Caco-2 Monolayers in the Absence or Presence of Quercitrin - A Mass Balance Study. Planta Med.

26. Kamuhabwa AR, Augustijns $P$, de Witte $P A(1999)$ In vitro transport and uptake of protohypericin and hypericin in the Caco-2 model. Int J Pharm 188: 81-86.
27. Leonhartsberger JG, Falk, H (2002) The protonation and deprotonation equilibria of hypericin revisited. Monatshefte für Chemie / Chemical Monthly Springer Link 133: 167-172.

28. Chowdhury PK, Ashby KD, Datta A, Petrich JW (2000) Effect of pH on the fluorescence and absorption spectra of hypericin in reverse micelles. Photochem Photobiol 72: 612-618.

29. ChEMBL (2017) Embl-ebi compound report card of pseudohypericin.

30. Buzova D, Kasak P, Miskovsky,P, Jancura D (2013) Solubilization of poorly soluble photosensitizer hypericin by polymeric micelles and polyethylene glycol. Gen Physiol Biophys 32: 201-208.

31. Gaedcke (2003) Herstell- und Qualitätsaspekte pflanzlicher Extrakte.

32. FDA (2015) Guidance for Industry: Waiver of in vivo bioavailability and bioequivalence studies for immediate-release solid oral dosage forms based on a Biopharmaceutics Classification System, Draft Guidance. U.S. Department of Health and Human Services, Food and Drug Administartion (FDA), Center for Drug Evaluation and Research (CDER).

33. Sheller RA, Cuevas ME, Todd, MC (2017) Comparison of transepithelial resistance measurement techniques: Chopsticks vs. Endohm. Biol Proced Online 19: 4.

34. Srinivasan B, Kolli AR, Esch MB, Abaci HE, Shuler, ML, et al. (2015) TEER measurement techniques for in vitro barrier model systems. J Lab Autom 20: 107-126.

35. Avdeef A, Tam KY (2010) How well can the Caco-2/Madin-Darby canine kidney models predict effective human jejunal permeability? J Med Chem 53: 35663584.

36. Stevens, JF, Maier CS (2016) The Chemistry of Gut Microbial Metabolism of Polyphenols. Phytochem Rev 15: 425-444.

37. Xue H, Xie W, Jiang Z, Wang M, Wang J, et al. (2016) 3,4-Dihydroxyphenylacetic acid, a microbiota-derived metabolite of quercetin, attenuates acetaminophen (APAP)-induced liver injury through activation of Nrf-2. Xenobiotica 46: 931939.

38. Walle T, Walle UK, Halushka PV (2001) Carbon dioxide is the major metabolite of quercetin in humans. J Nutr 131: 2648-2652.

39. Zaman M, Qureshi J, ljaz H, Sarfa, RM, Khan HU, et al. (2016) Oral controlled release drug delivery system and characteritzation of oral tablets: a review. PJPR 02. 